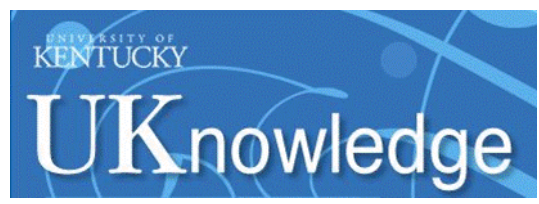

University of Kentucky

UKnowledge

Sanders-Brown Center on Aging Faculty

Publications

Aging

$2-5-2014$

\title{
Microsome Isolation from Tissue
}

\author{
Maria Bodero \\ University of Kentucky \\ Jose Francisco Abisambra \\ University of Kentucky, joe.abisambra@uky.edu
}

Follow this and additional works at: https://uknowledge.uky.edu/sbcoa_facpub

Part of the Physiology Commons

Right click to open a feedback form in a new tab to let us know how this document benefits you.

\section{Repository Citation}

Bodero, Maria and Abisambra, Jose Francisco, "Microsome Isolation from Tissue" (2014). Sanders-Brown Center on Aging Faculty Publications. 116.

https://uknowledge.uky.edu/sbcoa_facpub/116

This Article is brought to you for free and open access by the Aging at UKnowledge. It has been accepted for inclusion in Sanders-Brown Center on Aging Faculty Publications by an authorized administrator of UKnowledge. For more information, please contact UKnowledge@lsv.uky.edu. 


\section{Microsome Isolation from Tissue}

Digital Object Identifier (DOI)

https://doi.org/10.21769/BioProtoc.1038

\section{Notes/Citation Information}

Published in Bio-protocol, v. 4, issue 3, p. 1-3.

Copyright ( 92014 The Authors; exclusive licensee Bio-protocol LLC.

The publisher has granted the permission for posting the article here. 


\section{Microsome Isolation from Tissue}

Maria Bodero and Jose Francisco Abisambra*

Sanders-Brown Center on Aging and Department of Physiology, University of Kentucky, Lexington, USA

*For correspondence: joe.abisambra@uky.edu

[Abstract] This protocol details the extraction of microsomes from frozen tissue in order to further examine the protein-protein interactions occurring within the endoplasmic reticulum. This protocol was adapted from Abisambra et al. (2013) with modifications made in order to optimize for subsequent use.

\section{Materials and Reagents}

1. Sucrose

2. Protease Inhibitor cocktail, EDTA free (Merck KGaA, Calbiochem, catalog number: 539134)

3. Phosphatase inhibitor cocktail II

4. Phosphatase inhibitor cocktail III

5. PMSF at $10 \mathrm{mM}$ in DMSO or $1.74 \mathrm{mg} / \mathrm{ml}$ (Thermo Fisher Scientific, catalog number: 36978)

6. Phosphatase Arrest II cocktail (Geno Technology, catalog number: 786-451)

7. Phosphatase Arrest III cocktail (Geno Technology, catalog number: 786-452)

8. M-PER Mammalian Protein Extraction Reagent (Thermo Fisher Scientific, catalog number: 78501)

\section{Equipment}

1. Sterile bottle filter

2. Glass Dounce homogenizer

3. Refrigerated centrifuge

4. Microfuge tubes rated for at least $25,000 \times g$ centrifugation 


\section{Procedure}

1. Make a $0.25 \mathrm{M}$ sucrose solution that contains protease inhibitor cocktail, phosphatase inhibitor cocktails II and III, and PMSF as follows:

Per $100 \mu \mathrm{l}$ of Sucrose master mix add:
a. $96 \mu \mathrm{l}$ of $0.25 \mathrm{M}$ sucrose
b. $1 \mu$ l of protease inhibitor cocktail
c. $1 \mu \mathrm{l}$ of phosphatase inhibitor cocktail II
d. $1 \mu \mathrm{l}$ of phosphatase inhibitor cocktail III
e. $1 \mu \mathrm{l}$ of PMSF

2. Weigh tissue to be analyzed and add 10x its mass in volume of sucrose master mix (see step 1; i.e. $100 \mathrm{mg}=1,000 \mu \mathrm{l}$ of sucrose solution).

3. While keeping all solutions on ice, add the appropriate amount of sucrose solution to tissue and dounce homogenize until a completely homogenous solution is obtained.

4. Spin the homogenate at $10,000 \times g$ for $10 \mathrm{~min}$ at $4{ }^{\circ} \mathrm{C}$.

5. Transfer the supernatants to a new microfuge tube (save the pellet at $-20^{\circ} \mathrm{C}$ ) and spin at $30,000 \times g$ for $90 \mathrm{~min}$ in a fixed angle rotor (or at 25,800 $\times \mathrm{g}$ for $2 \mathrm{~h}$ ).

6. Transfer the supernatant to a different microfuge tube and save at $-20^{\circ} \mathrm{C}$. The remaining pellet corresponds to the microsomal fraction.

7. Pipette gently to resuspend the microsome pellet in $200 \mu \mathrm{l}$ of the following mix (per 100 $\mu l)$ :
a. $96 \mu$ l of MPER buffer
b. $1 \mu$ of protease inhibitor cocktail
C. $1 \mu \mathrm{l}$ of phosphatase arrest cocktail II
d. $1 \mu$ of phosphatase arrest cocktail III
e. $1 \mu \mathrm{l}$ of PMSF

\section{Acknowledgments}

We thank Dr. Gene Ness, Dr. Huntington Potter, and Dr. Chad Dickey for supporting the development and adaptation of this protocol in their labs. We credit the following article for this work: Abisambra et al. (2013). Financial support during the time of protocol development came from the Alzheimer's Association NIRGD-12-242642, the Foundation for PSP/CBD and Related Brain Disorders (6144107400), and NIH/NIA ADC Pilot Grant from 5P30AG02838308. 


\section{biö-protocol}

\section{$\underline{\text { References }}$}

1. Abisambra, J. F., Jinwal, U. K., Blair, L. J., O'Leary, J. C., 3rd, Li, Q., Brady, S., Wang, L., Guidi, C. E., Zhang, B., Nordhues, B. A., Cockman, M., Suntharalingham, A., Li, P., Jin, Y., Atkins, C. A. and Dickey, C. A. (2013). Tau accumulation activates the unfolded protein response by impairing endoplasmic reticulum-associated degradation. $J$ Neurosci 33(22): 9498-9507.

2. Abisambra, J. F., Fiorelli, T., Padmanabhan, J., Neame, P., Wefes, I. and Potter, H. (2010). LDLR expression and localization are altered in mouse and human cell culture models of Alzheimer's disease. PLoS One 5(1): e8556. 